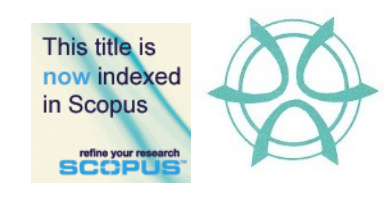

\title{
DETERMINANTS OF PUBLIC ASSET VALUE FOR LAND PROPERTY: A STUDY IN THE CITY OF TANGERANG, INDONESIA
}

\author{
Intan Puspitarini' ${ }^{1}$, Irfan Rachmat Devianto ${ }^{2}$ \\ ${ }^{1}$ Department of Financial Management, \\ POLYTECHNIC OF STATE FINANCE \\ ${ }^{2}$ State Asset Management, \\ MINISTRY OF FINANCE OF THE REPUBLIC OF INDONESIA
}

\begin{abstract}
Public lands take a huge portion of the government balance sheet in many countries, necessitating the need to reevaluate public assets for accurate financial reports, informed decisions, and optimized performance in strategic asset management. This study aimed to determine how the land area, location, shape, road width, and distance to the $\mathrm{CBD}$ affect the value of public land. A quantitative method with multiple regression was used to analyze primary data collected from the Public Asset Revaluation Report in the City of Tangerang from 2017 to 2018. The subject was made of 62 plots of public land chosen through population sampling. The results showed that land area and distance to the CBD significantly and negatively affected the public property value, while the road width had a positive effect. However, the location and shape of the public land did not affect its value.
\end{abstract}

Keywords: Strategic Asset Management, public property fair value, City of Tangerang, public asset revaluation

\footnotetext{
${ }^{1}$ Lecturer at Polytechnic of State Finance STAN. Indonesia Ministry of Finance. Email: intan.puspitarini@pknstan.ac.id
} 
PLANNING MALAYSIA

Journal of the Malaysia Institute of Planners (2021)

\section{INTRODUCTION}

Land property has similar characteristics to buildings, such as being immovable, long-lasting, scarce, and dependant on other production factors (Whipple, 1995). In general, land property continues to appreciate in value because it has fixed supply and rising demand. The Indonesian Minister of Finance, also acts as a public asset manager, controlling the Central Government's land property. This authority is then delegated to the Directorate General of State Asset Management (DGSAM). From 2017 to 2018, DGSAM held an Asset Revaluation Program for public assets, including land, building, roads, and dams, to establish their true value.

The government used a market data approach during the valuation process. In this case, the property being valued is compared with similar recent sales in the area. DGSAM provided public valuers with the Appraisal Guidelines for compliance with the valuation requirements and consistency. The guideline primarily focused on the object under relation. Potential factors that could affect the property value were selected, analyzed, and made necessary adjustments to account for the difference when estimating market value. According to previous studies, road width and distance from the property to the Central Business District (CBD) affect land value (Bintang et al., 2017; Aulia (2005); Olawande (2011); Sutarmin (2012); Mariada et al. 2014). However, the Appraisal Guidelines did not include them as adjustment factors in valuing the public land property. Most previous studies examined private land property while ignoring public assets, hence there is a need to examine factors affecting the public land property. This study focused on Tangerang, Province of Banten in Indonesia. The findings were expected to provide information to the government for revising The Appraisal Guidelines policies.

Apart from the introduction, this paper has additional 5 Sections. Section 1 presents a literature review, covering a discussion on land property determinants and develops a framework. The methodology is described in Section 2. Section 3 presents data analysis and results, while 4 and 5 present the paper conclusion and the limitation of the study

\section{LITERATURE REVIEW}

\section{Previous Research}

Various studies have examined land and real estate property valuation, each proposing different valuation methods, determinants, and object's location. However, they all agree that location is one factor that affects land value. Some studies define location as distance to CBD while others use it in general. Eckert (1990) indicated that land property value is affected by the area of the land, front width, its position on the road, and shape. Another study with a specific definition of location reported that the distance and accessibility to the CBD via private or public transportation affects property value (Hromada, 2018). Hasan et al. (2019) 
Intan Puspitarini, Irfan Rachmat Devianto

Determinants Of Public Asset Value for Land Property: A Study in The City of Tangerang, Indonesia

also defined the location variable as the distance to residential neighborhoods and employment centers. This is in line with another study conducted in Shanghai, China (Chena et al., 2008), which showed that housing prices were impacted by their distance to CBD and the availability of mass transportation (subway). The further away the house is from the CBD, the lower its price. Easy access to the subway was found to increase housing value sharply. A similar result was also recorded in the city of Semarang by Rakhmatulloh et al. (2019), which concluded that land prices were significantly affected by the proximity and the ease of access to the city center of Semarang. Studies in Greater Jakarta show that proximity to CBD affects property value.

A study conducted in Bekasi, Indonesia, to establish the relationship between land value and distance to the CBD in urban structure in Bekasi (Yowaldi, 2012) demonstrated that the distance to the CBD affects land value in the area. Though Yowaldi's study primarily focused on one part of Greater Jakarta (Bekasi), a different study by Andrayani examined all parts of Greater Jakarta (Andrayani et al., 2014) and found that population density and the distance to the CBD area in Jakarta have impacted land value. Bintang et al. (2017) claimed that the ability of the surrounding community also affects property value since an increase in the surrounding community's purchasing power will lead to an increase in property value around it. This study also indicated a higher demand for a property close to the CBD and has wide road access. A study by Sutarmin (2012) agrees with these findings, indicating that location positively influences property values.

Though these studies give a different definition of location, they agree that it affects land value. Nevertheless, the above studies were focused on private land and private real estate property. No research has focused on factors affecting the public land property, despite the Appraisal Guidelines stating that public land value is affected by land area, location, and shape. This study aimed to determine if two other factors (distance to CBD and road width) in the previous studies affect the value of the public land property.

\section{Framework}

The framework of the study is discussed below in Figure I. 


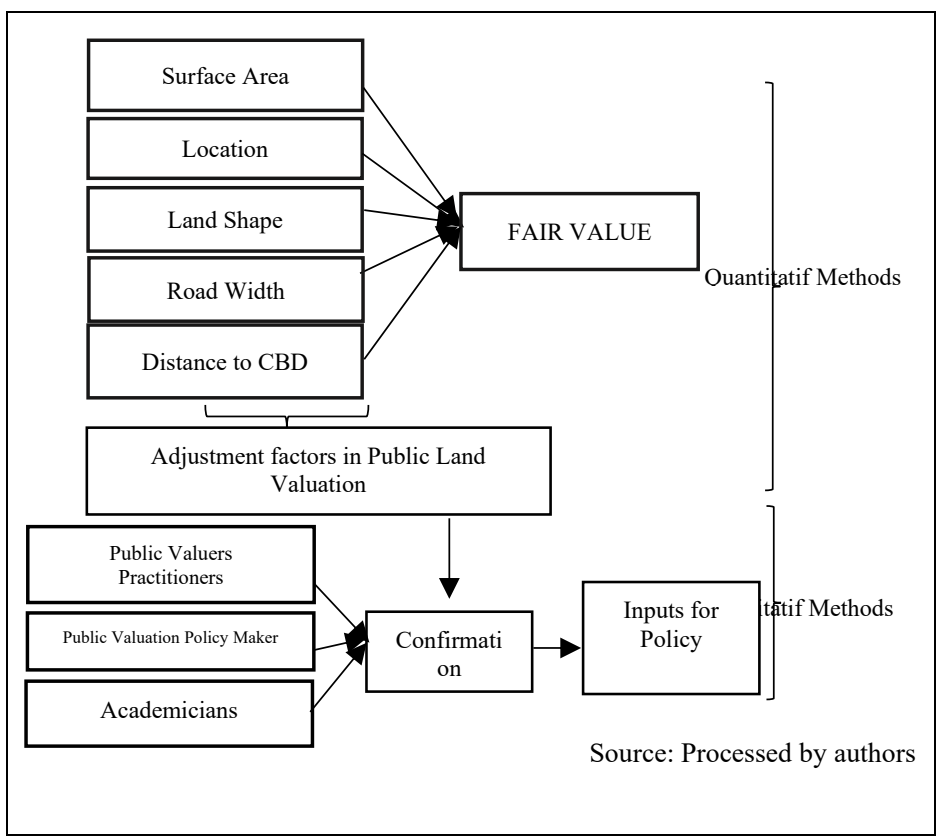

Figure 1. Framework

\section{Research Background}

Tangerang is located west of Jakarta, the capital city of Indonesia. It is the largest city in Banten Province but falls behind Jakarta and Bekasi in Greater Jakarta. Tangerang is considered densely populated with $1,771,092$ people by 2019 . This means that for every square kilometer, there were 10,763 people, making it one of the densest cities in Indonesia (the official website of Tangerang City Government, 2020). Tangerang city is strategically located as it serves as the west entrance to Java Island from Sumatra Island. Apart from its strategic location, Tangerang also boosts several labor-intensive industries and a freeway, improving its dynamic and growth. Additionally, the Soekarno-Hatta international airport adds to the exclusive value of the city, making it a capital city. Tangerang also has many public assets, including buildings, offices, jails, sports centers, schools, hospitals, and airports. These public properties fall under respective line ministries under the coordination of the Indonesia Central Government. Indonesian public land properties are also managed by DGSAM as authorized by the Minister of Finance, considered the Public Asset Manager.

Angotti (1993) alluded that a metropolitan city has ease of mobility as their unique characteristic that could influence property value. Winarso (2006) divided mobility into three categories: job mobility, housing mobility, and travel mobility. Tangerang city has all three forms of mobility; therefore, it qualifies as a metropolitan city. 
Intan Puspitarini, Irfan Rachmat Devianto

Determinants Of Public Asset Value for Land Property: A Study in The City of Tangerang, Indonesia

\section{METHODOLOGY}

This study combines qualitative and quantitative methods for a better understanding. The Sequential Explanatory Strategy was used to attain a perfect mix, where quantitative data are collected and analyzed first, followed by the collection and analysis of qualitative data in a second phase to build the results of the initial quantitative method (Morse in Cresswell, 2008). The initial quantitative analysis results inform the secondary qualitative data collection, meaning that the two forms of data are separated but connected.

Both secondary and primary sources of data were used. The secondary data was obtained from the 62 documents on Valuation Reports and paperwork from the Revaluation Program held in 2017-2018 in Tangerang. Data concerning land size, location, and shape were collected from paperwork. Additional information on land properties' value and location wee also acquired from the Valuation Reports. Other secondary sources, such as a copy of land certificates, provided data on land property. The data on road width and distance to the CBD were obtained through direct measurements in the field. Another primary source of data included interviews performed on a triangular basis.

\section{Hypothesis}

This study's hypothesis is tested through quantitative methods by data verification in the field. Hypotheses constructed in this research are as follows:

H 1: Public Land Property Surface Area effect on the value of the land property per square meter;

H 2: Public Land Property Location effect on the value of the land property per square meter;

H 3: The shape of the ground effect on the value of the land property per square meter;

$\mathrm{H}$ 4: Distance ground to CBD effect on the value of the land property per square meter;

H 5: Road Width around the parcel of land effect on the value of the land property per square meter.

\begin{tabular}{|c|c|c|c|c|}
\hline $\begin{array}{c}\text { QUAN } \\
\text { Data } \\
\text { Collection }\end{array}$ & $\begin{array}{c}\text { QUAN } \\
\text { Data } \\
\text { Analysis }\end{array}$ & $\begin{array}{c}\text { qual } \\
\text { Data } \\
\text { Collection }\end{array}$ & $\begin{array}{c}\text { qual } \\
\text { Data } \\
\text { Analysis }\end{array}$ & $\begin{array}{c}\text { Interpretation } \\
\text { of Entire } \\
\text { Analysis }\end{array}$ \\
\hline
\end{tabular}

\section{Research Model}

Semilog Model with multiple linear regression analysis is used in this study. The model measures the absolute changes of the dependent variable $(\mathrm{Y})$ over the relative changes of independent variables (X1, X2, X3, etc.).

Based on the review literature and research beforehand, this study uses the following variables:

NTNH= Public Land Property Value per $\mathrm{m} 2$ (in units of currency rupiah) 
PLANNING MALAYSIA

Journal of the Malaysia Institute of Planners (2021)

LUAS= Size of Land (in units of square meters)

LOKS= Location (discrete data)

$\mathrm{BTNH}=$ Land Shape (discrete data)

$\mathrm{JCBD}=$ Distance to the CBD (in units of meters)

$\mathrm{LBJL}=$ Width of the Road (in meters)

The model constructed is as follows:

$N T N H=\beta 0+\beta_{1} L n L U A S+\beta_{2} L n L O K S+\beta_{3} L n B T N H+\beta_{4} L n J C B D+\beta{ }_{5} L n L B J L+e$

The definitions of variables above are:

a) Public Land Property Value (NTNH) is the fair value per the Public Valuers based on the market value of surrounding properties (measured in units of rupiah currency per square meter).

b) Size of Land Property (LUAS) island area of the object being valued (measured in square meters).

c) Location (LOKS) is the location where the public land property is, with value score (1) indicating that the location is good, value score (2) location is moderate, and value score (3) poor location.

d) Land Shape (BNTH) in the form of land property, with value score (1) signifying land is square, value score (2) showing trapezoidal or parallelogram shape, and value (3) is given to any other shape.

e) Distance to the CBD (JCBD) is the distance taken from the land property location to the nearby CBD, measured in meters.

f) The width of the Road (LBJL) is the width of roads that accesses the land property, measured in meters.

\section{DATA ANALYSIS AND RESULTS}

\section{Quantitative Analysis}

The vertical offices of DGSAM in Tangerang (KPKNL Tangerang I and II) conducted Public Asset Revaluation from 2017 to 2018 on 62 public land properties in an area covering 11,683.76 square meters, and the result of all variables are depicted in the table below.

Table 1. Description of Statistical Data

\begin{tabular}{|l|l|l|l|l|l|l|}
\hline & NTNH & LARGE & LOKS & BTNH & JCBD & LBJL \\
\hline N & 62 & 62 & 62 & 62 & 62 & 62 \\
The mean & 8777700.97 & 11683.76 & 1,161 & 1,565 & 2970.19 & 7.58 \\
Median & 7274645.50 & 1244.50 & 1,000 & 1,000 & 2579.50 & $6: 00$ \\
Std. Deviation & 4761976.73 & 61373.03 & .3708 & .8223 & 2238.34 & 3.59 \\
Minimum & 2874400.00 & 112 & 1.0 & 1.0 & 300.0 & 3.0 \\
Maximum & 18288064.00 & 479717 & 2.0 & 3.0 & 10611.0 & 20.0 \\
\hline
\end{tabular}


Intan Puspitarini, Irfan Rachmat Devianto

Determinants Of Public Asset Value for Land Property: A Study in The City of Tangerang, Indonesia

\section{Regression Analysis}

The data used in this study has met the BLUE criteria (Best, Linear, Unbiased, and Estimator). Tests done include normality test, multicollinearity test, autocorrelation test, and heteroscedasticity test. The data is further processed through the regression analysis, as exhibited in Table 2 below.

Table 2. Regression Analysis Results

\begin{tabular}{|c|c|c|c|c|c|}
\hline \multirow{2}{*}{ Model } & \multicolumn{2}{|c|}{ Unstandardized Coefficients } & Std. Coeff & \multirow{2}{*}{$\mathrm{T}$} & \multirow{2}{*}{ Sig. } \\
\hline & B & Std. Error & Beta & & \\
\hline (Constant) & 33739228,233 & 7363081,836 & & 4,582 & .000 \\
\hline LUAS & -642950.257 & 371290,900 & .215 & $-1,732$ & .089 \\
\hline INLOKS & $-2164799,859$ & 2241292,983 & -.117 & -966 & 338 \\
\hline LnBTNH & -1412843.705 & 1105524,995 & -.138 & -1.278 & 207 \\
\hline LnJCBD & $-3112286,362$ & 684696,783 & -.515 & $-5,545$ & .000 \\
\hline LnLBJL & 2283345,943 & 1167489,510 & 218 & 1956 & .055 \\
\hline
\end{tabular}

Source: Adapted from document Reports Results Assessment

Based on Table II equation obtained from the regression are as follows:

NTNH $=$-642,950.26 LnLUAS - 2,164,799.86 LnLOKS - 1,412,843.71

LnBTNH - 3,112,286.36 LnJCBD + 2,283,3345.94 LnLBJL + 33,739,228.23

The result of this study indicates that the five variable independents; LUAS, LOKS, BNTH, JCBD, and LJBL, simultaneously contributed to a $45.8 \%$ change in Land Property Value (dependent variable), with external factors contributing to the remaining $54.2 \%$. The external factors include documents of land ownership, zoning, land elevation, and macroeconomic factors. The model can also be interpreted as follows:

a) The hypothesis that LUAS harms the value of public land property in Tangerang is accepted, meaning that a $1 \%$ increase of land area reduces the land value by Rp.6,429.50. This is because a 1\% increase in land property area will reduce the society's purchasing power by Rp.6,429.50. Increasing land supply in the market will make it difficult for landowners to sell, thus reducing their prices.

b) The hypothesis that the Location of Public Land Property (LOKS) impacts land property value in Tangerang is rejected since almost all public land properties are located in strategic locations. Additionally, these properties have good access and facilities; thus, LOKS variable does not significantly affect the value of the public land property.

c) The hypothesis that Land Shape (BNTH) affects the value of public land property in Tangerang is rejected because almost all public land properties in the area are in good shape (squares or rectangles), meaning that the BNTH variable does not affect land value. 
PLANNING MALAYSIA

Journal of the Malaysia Institute of Planners (2021)

d) The hypothesis that the distance of the public land property to the CBD (JCBD) negatively affects the value of public land property in Tangerang is accepted. The study established that a $1 \%$ increase in distance of the ground to the CBD reduces its value by $\mathrm{Rp} 31.122,86$.

e) The hypothesis that the Width of the Road to the property positively affects the value of public land property in Tangerang is accepted, meaning that a $1 \%$ increase in the road width adds to the land value by Rp22.833,45.

\section{Qualitative Analysis}

A list of main interview questions was generated during qualitative analysis before respondents were interviewed. The use of open-ended questions to Policy Makers on public, Government Valuers, Practitioners' valuation, and academicians resulted in better outcomes. The questionnaires were based on issues from the public land property revaluation program from 2017 to 2018, including the methods used in the valuation and adjustment factors. Respondents' opinions on Distance to CBD, road width, and the urgency of revising the Guideline to accommodate these two variables were also asked. The questions can be developed according to the answers from the sources.

a. Valuation Method used during Revaluation of Public Land Property

Valuers were given the freedom to choose the valuation method, market prices, costs, and revenues method. They all chose the market price method as the best method in the valuating of public land property. Using the market price approach, valuers carried out a field survey to determine the surrounding land, obtain comparative data, create adjustment factors, weigh each related factor, and develop a fair value opinion of the property being valued.

Table 3. Valuations Method Applied in Revaluation of Public Land Property Source: Results of interview sources

\begin{tabular}{|l|c|}
\hline \multicolumn{1}{|c|}{ Interviewees } & Results \\
\hline Government Valuer Practitioners & Market price method \\
\hline Policy Makers (DGSAM) & Market price method \\
\hline Academicians & Market price method \\
\hline
\end{tabular}

\section{b. Adjustment Factors Used in Valuation.}

This study shows that each respondent has different opinions and reasons regarding different adjustment factors and the weights placed on the valuation. Government Valuers Practitioners argue that emphasis should be laid on legal, financial, maximization, and physical condition aspects as adjustment factors. In contrast, Policy Makers (DGSAM) reason that valuers should consider all factors in the Guidelines, including location, type, area, shape, size, contour, elevation, public facilities, zoning, permits, legal documents, and other related 
Intan Puspitarini, Irfan Rachmat Devianto

Determinants Of Public Asset Value for Land Property: A Study in The City of Tangerang, Indonesia

factors. Academicians also have a different view, arguing that relevant adjustments factors are demand, utility, scarcity, transferability, accessibility, and zoning. Moreover, they also indicated through their response that private sectors will consider additional adjustment factors, such as frontage (front width). The three categories of respondents agree that zoning and accessibility to the property are adjustment factors that affect property value.

Table 4. Adjustment Factors Used in Valuation

\begin{tabular}{|l|l|}
\hline Interviewees & \multicolumn{1}{|c|}{ Results } \\
\hline $\begin{array}{l}\text { Government Valuer } \\
\text { Practitioners }\end{array}$ & $\begin{array}{l}\text { Legal Documents, Size, Contour, Elevation, Location, } \\
\text { Accessibility, Zoning }\end{array}$ \\
\hline Policy Makers (DGSAM) & $\begin{array}{l}\text { Legal Documents, Size, Contour, Elevation, Location, } \\
\text { Zoning, }\end{array}$ \\
\hline Academicians & $\begin{array}{l}\text { Demand, Utility, Scarcity, Transferability, } \\
\text { Accessibility and Zoning. }\end{array}$ \\
\hline
\end{tabular}

Source: Results of interview sources

c. Distance to CBD and Road Width as Adjustment Factors.

All the respondents agreed that valuers should know what qualifies a place as a CBD. The academicians suggest that CBD is a place where people interact and do business; however, several centers of interaction and business may not necessarily be a CBD. Road width is its ability to accommodate vehicles, making the object of valuation easy to access. The respondent agreed that these two factors affect property land value; nevertheless, it is up to valuers to determine if they will consider them as adjustment factors. The following Table 5 summarize the interview result regarding Distance to CBD and Road Width as adjustment factors:

Table 5. Effect of Distance Soil into CBD And Lebar Road Against Opinion Value

\begin{tabular}{|l|l|}
\hline \multicolumn{1}{|c|}{ Interviewees } & \multicolumn{1}{c|}{ Results } \\
\hline $\begin{array}{l}\text { Government Valuer } \\
\text { Practitioners }\end{array}$ & $\begin{array}{l}\text { Have an effect by considering surrounding } \\
\text { conditions }\end{array}$ \\
\hline Policy Makers (DGSAM) & $\begin{array}{l}\text { Have an effect by considering surrounding } \\
\text { conditions }\end{array}$ \\
\hline Academicians & $\begin{array}{l}\text { Have an effect by considering surrounding } \\
\text { conditions }\end{array}$ \\
\hline
\end{tabular}

Source: Results of interview sources

d. The urgency of revising the Appraisal Guideline to accommodate the Distance to CBD and Road Width as Adjustment Factors.

Government Valuer Practitioners state that each valuation object and region is unique and can contribute to different weights on the adjustment factor. However, the respondent from Policy Makers (DGSAM) indicates no urgency in revising the Guideline because of different regional characteristics. They 
PLANNING MALAYSIA

Journal of the Malaysia Institute of Planners (2021)

argue that public valuers have the freedom to choose which adjustment factors impact the property being valued. However, it is better if they explore those given in the Appraisal Guidelines. The academicians' reason that revising the Guidelines would limit the valuers, making the valuation process more rigid. They argued that valuers should undertake market research in the property's region to determine influencing factors. The general response from all respondents confirmed that the government doesn't need to revise the Guidelines, suggesting market research as a tool valuers can use in determining what qualifies as an adjustment factor. Moreover, DGSAM has agreed to maximize the use of Geotagging to equip public valuers in performing market research to connect to the latest database regarding the conditions of the object.

Table 6. The Urgency of Revising the Appraisal Guideline to Accommodate the Distance to CBD and Road Width as Adjustment Factors

\begin{tabular}{|l|l|}
\hline Interviewees & Results \\
\hline Government Valuer Practitioners & $\begin{array}{l}\text { No need, because each region has its own } \\
\text { uniqueness }\end{array}$ \\
\hline Policy Makers (DGSAM) & No need, it hasn't become an urgency yet \\
\hline Academicians & No need, because it will restrict the valuers \\
\hline
\end{tabular}

\section{CONCLUSION}

This study shows that public land property value in Tangerang is $45.8 \%$ affected by five independent variables, including the size, location, shape, distance to the $\mathrm{CBD}$, and the width of the road. However, the Appraisal Guidelines do not include two adjustment factors considered in this study: the distance to the CBD and the width of the road. Furthermore, qualitative analysis shows that these two factors influence land value with all respondents consenting to the claim. Nevertheless, some respondents reasoned that revising government guidelines is not a priority as they could limit the valuation process. Therefore, valuers should use market research to determine which determinant factors affect the property undervaluation. The use of Geotagging will help all public valuers access the latest data for market research.

THE LIMITATION OF THE STUDY AND FURTHER RESEARCH

This study's focus is limited to identifying the distance to the CBD and the width of the road as additional variables that should be considered in valuing public land property, with Tangerang as an area of study. The result from this study is generalized, thus subject to limitations, such as the uniqueness of various valuation objects in each region. Therefore, there is a need for additional research 
Intan Puspitarini, Irfan Rachmat Devianto

Determinants Of Public Asset Value for Land Property: A Study in The City of Tangerang, Indonesia

covering various parts of Indonesia for more insight for policymakers, public valuers, and academicians.

\section{ACKNOWLEDGEMENT}

The authors wish to express sincere gratitude to the DGSAM, Ministry of Finance, for making this study possible by providing the required data. The authors are also grateful to Polytechnic of State Finance, Ministry of Finance of the Republic of Indonesia for its support.

\section{REFERENCES}

Andrayani, Andrayani; Wihardi, Didi; and Susilowati, Yuliana. 2014. A Pattern of Land Value in Bodetabek Area. Kuala Lumpur, Malaysia: FIG Congress.

Aulia, Nuril Fikri. 2005. Faktor-Faktor yang Mempengaruhi Nilai Tanah Kajian Nilai Tanah Lingkungan Kampus dan di Sekitar Lingkungan Kampus (Studi di Kawasan Jatinangor Sumedang Jawa Barat). Yogyakarta: Tesis Pasca Sarjana UGM.

Bintang, Andika Presley, Tri Oldy Rotinsulu, Daisy S.M. Engka. 2017. Analisis FaktorFaktor yang Mempengaruhi Nilai Tanah di Kota Manado. Manado: Fakultas Ekonomi dan Bisnis Universitas Sam Ratulangi.

Chena, Jie and Hao, Qianjin. 2008. The Impacts Of Distance To CBD On Housing Prices In Shanghai: A Hedonic Analysis. China: Journal of Chinese Economic and Business Studies.

Creswell, John W. 2008. Research Design: Qualitative, Quantitative and Mixed Methods Approach. California: SAGE Publications.

Dadi, Iwan Hindawan, Arik Hariyono, Darmawan Dwi Atmoko. 2006. Fundamental of Valuation Teori dan Aplikasi Penilaian Properti. Jakarta: Lembaga Pengkajian Keuangan Publik dan Akuntansi Pemerintah (LPKPAP).

Denhardt, Robert B., Janet Vinzant Denhardt. 2000. The New Public Service: Serving Rather Than Steering. Public Administration Review Vol. 60, No.6 (Nov. - Dec. 2000), pp. 549-559.

Eckert, J.K. 1990. Property Appraisal and Assesment Administration. IAAO. Chicago. Illinois.

Fahirah F, Amin Basong, Hermansyah H. Tagala. 2010. Identifikasi Faktor yang Mempengaruhi Nilai Jual Lahan dan Bangunan Pada Perumahan Tipe Sederhana. Palu: Universitas Tadulako.

Hassan, Mohd Azren; Abdullah, Yusfida Ayu; Omar, Dasimah; Danial, Muhammad Hakim. 2019. Location Housing Affordability Index: Analysing the Relationships. Journal of the Malaysian Institute of Planners, Vol. 19, Issue 1 (2021), pp 41-52.

Hromada, Eduard. 2018. Analysis of Relationship Between Market Value of Property and Its Distance from Center of Capital. Czech Technical University: Prague, Czech Republic.

Oni, Ayotunde Olawande. 2011. Land Value Determinants and Rental Values of Office Space in Ikeja. Mediterranean Journal of Social Sciences vol.2, No.2, May 2011.

Pemerintah Kota Tangerang. https://tangerangkota.go.id (diakses 11 Juni 2020). 
Rakhmatulloh, Anita Ratnasari; Buchori, Imam; Pradoto, Wisnu; Riyanto, Bambang. The Power Of Accessibility To Land Price In Semarang Urban Corridors, Indonesia. Journal of the Malaysian Institute of Planners, Vol. 16, Issue 1 (2018), pp 118-129.

Rijasa, M. Mariada, M. Sukrawa, Mayun Nadiasa. 2014. Analisis Penilaian Bangunan Rumah Tinggal Di Kota Denpasar. Jurnal Spektran Vol.2 No.2 Juli 2014. Badung: Universitas Udayana.

Sutarmin, 2012, Determinan Nilai Likuidasi Real Property (Studi Eksekusi Lelang PUPN Pada Kantor Pelayanan Kekayaan Negara dan Lelang Madiun Tahun 2008-2010), Yogyakarta: Tesis Pascasarjana UGM.

Whipple, R.T.M. 1995. Property Valuation and Analysis. Sydney: Law Book Company Winarso, Haryo. 2006. Metropolitan di Indonesia: Kenyataan dan Tantangan dalam Penataan ruang. Direktorat Jenderal Penataan Ruang, Departemen Pekerjaan Umum.

Yowaldi, Yowaldi. 2012. The Relation between Land Price and Distance to CBD in Bekasi. Institute of Social Studies, The Netherlands: A Research Paper.

Received: $12^{\text {th }}$ July 2021. Accepted: $23^{\text {rd }}$ Sept 2021 